\title{
Banking sector reforms and output growth of manufacturing sector in Nigeria (1970-2011)
}

\author{
Olanrewaju, Oluwagbenga Gideon ${ }^{1 *}$, Aremo, Adeleke Gabriel $^{2}$ and Aiyegbusi Oluwole \\ Oladipo $^{2}$
}

${ }^{1}$ Department of Economics, Babcock University, Ilisan, Remo, Ogun State, Nigeria.

${ }^{2}$ Department of Economics, Obafemi Awolowo University, Ile-Ife Nigeria.

Received 27 December, 2014; Accepted 15 July, 2015

\begin{abstract}
The study investigated empirically the effect of banking sector reforms on the output of manufacturing sector in the Nigerian economy between 1970 and 2011 with a view to examining the extent of the impact of banking sector reforms on the manufacturing sector. The study employed annual secondary time series data from 1970-2011, sourced from the Central Bank of Nigeria's statistical bulletin and annual report and statement of accounts, National Bureau of Statistics final accounts and IMF International Financial Statistics (IFS) using the methodology of Cointegration analysis and Error Correction Mechanism (ECM). The empirical results showed that the effects of Bank assets, Lending rate, Exchange rate and real rate of interest on manufacturing output were positively significant but with very low impact. On the other hand, the financial deepening and interest rate spread negatively and significantly impacted on the output growth of manufacturing sector in Nigeria. Overall, the conclusion that emerged from the findings suggests that the effects of banking sector reforms on the output growth of manufacturing sector were significantly low in the Nigerian economy. However, the findings indicated that the impacts of the various banking reforms could vary widely on the economy depending on the time lags involved. Consequently, the policymakers must be prepared to initiate proper countercyclical banking reforms that will serve as buffer measures to lessen or abort the negative impacts of any banking reforms on the manufacturing output growth. Thus a flexible accommodating banking reform regime is advocated for Nigeria.
\end{abstract}

Key words: Banking sector reforms, Error Correction Mechanism (ECM), manufacturing sector, and Cointegration analysis.

\section{INTRODUCTION}

The banking sector represents the nucleus of the financial system in an economy; thus it constitutes a potent and frontline economic policy tool in the hand of the monetary authorities for realizing key macroeconomic policy objectives. A well-functioning banking sector is sufficient to jump-start a sustainable economic growth. Hamilton (1781) opined that "banks were the surest engines that ever were invented for spurring economic growth." The recent experience in Eastern Europe and Asia has shown that countries that moved quickly to fix

*Corresponding author. E-mail: golarenwaju@yahoo.com

Authors agree that this article remain permanently open access under the terms of the Creative Commons Attribution License 4.0 International License 
their banking industry were able to achieve a sustainable growth rate than those that did not. This indicates that there is a causation that runs from banking sector development through the manufacturing sector to economic growth. Banks originate and facilitate financing which are fundamentally necessary for carrying out productive investments (Akingbola, 2001; Bukhari, 2005; Carbo; 2007)

A large body of the literature on development reveals that the services provided by well - developed financial intermediaries such as banks are essential drivers for innovation and growth (Bencivenga and Smith, 1991; King and Levine, 1993; Levine, 1997; Levine and Zervos, 1998; Loayza et al., 2000; Graff and Karmann, 2001) among others. In contrast, explanation initiated by Robinson (1952) posited that finance does not exert a causal impact on growth and that the findings of causations are somewhat misleading. Rather than this, banking development may follow real sector growth as a result of higher demand for financial services; hence the financial system grows in response to economic expansion. As economic activities grow, there will be more demand for both physical and liquid capital, such that the growth in manufacturing sector induces the financial sector to expand, and thereby increasing competition and efficiency in the financial intermediaries.

Based on the above controversies related to the causal impact of banking reforms on growth, the study examined the impact of banking reforms on manufacturing sector growth considered as a crucial subsector of the real sector. The need to examine this impact is borne out of the following reasons: First, it will enable the policy makers to assess the contribution of the extant banking reforms to real sector growth and to overall growth of the economy. Second, it enables the policy makers to predict when best to reshuffle and substitute any unproductive banking reforms strategies that are not meeting the desired goal of achieving the pre-determined output growth in the economy. Third, there is the likelihood that variants of reform strategies making up a menu of reforms may not likely have the same effects on real sector output growth. The present study therefore contributes to the literature by examining the individual effects of each of the banking sector reform instruments to manufacturing output growth.

The remaining presentation is organized into four sections. The theoretical and empirical issues are examined in section 2. The methodology is contained in section 3. Section 4 provides the empirical results while the last section contains the concluding remarks and policy implications

\section{THEORETICAL AND EMPIRICAL ISSUES}

The evolutionary theory of debt-intermediation claims that bankers were actually big merchants or firms which evolved from loaning their excess funds to other merchants or firms, to discounting bills of exchange and to issuing their own bills. These merchant bankers relied on their own equity to perform banking operations. They do not only enable the economic transactions but also anticipate them by creating their own bills for the future economic transactions. Thus, as more equity capital is built via retained profits, the merchant bankers begin to lend and then learnt the skills of screening, selecting and monitoring. "They start mobilizing deposits and accumulating increasingly diversified loan portfolios as their quality skills and capabilities of screening, selection and monitoring improved" (Winkler, 1998). The popular view underlying these theories is that in a world of information asymmetry, high transaction costs and moral hazard (which result in adverse selection), banks not only have to mobilize and allocate savings but they also have to exert corporate control manage risks to lower the cost of researching potential investments (Levine, 1997).

Fama (1980) applied the Modigliani-Miller (MM) theorem of irrelevance pure financing decision to banking sector. He found that portfolio management activity of banks under strong MM theorem is irrelevant to economic activities. However, the role of a competitive banking sector in a general equilibrium is passive. Johnson (1986) in a similar study observed the same line of argument by assuring that a competitive banking system would be under constant incentive to expand the nominal money supply and thereby initiating inflation. Thus if finance is money, and money is a veil financial development is a neutral factor in real economic development since increase in banking operations leads to increases in money supply, and so, inflationary prices. By implication, increasingly better resource allocation depresses saving rates such that growth is retarded (Levine et al., 2000).

In a response to the question "does finance cause economic growth?" King and Levine (1993) explored the Schumpeter's statement that "banker authorizes people in the name of society as it were to innovate". They used various measures of financial development in 12 regression equations and found that all the indicators of intermediation development are strongly associated with real per capita GDP growth, the rate of physical capital accumulation and improvements in the efficiency with which economies employ physical capital. They also show that commercial banks advance credits better than any other financial institutions and this is due to the risk sharing information services provided by commercial banks. However, their findings are not tantamount to the conclusion that finance causes growth; but it may be that finance is only a leading factor.

Levine and Zervos (1998) extend the work of King and Levine to include the independent impact of stock markets, as well as banks, on real economic growth. They found that stock market liquidity and banking sector 
development are independently and positively correlated with both current and future rates of capital accumulation and economic growth. Similarly, Bencivenga and Smith (1991) assert that "the introduction of financial development in any economy shifts the composition of savings towards capital, causing intermediation to be growth promoting". However, the major objection to the views of King and Levine (1993) and Levine and Zervos (1998) is that of unobserved differences in industrial composition across countries which tend to explain both the variance observed in financial development and the variance observed in growth.

Greenwood and Javanovic (1990) in their study employed an endogenous growth model to demonstrate that there is a positive two-way causal relationship between output growth and financial sector development. They opined that, the process of growth stimulate higher borrowing requirements for working capital and investments, thereby necessitating the entry and expansion of more banking institutions. While the process of financial intermediation by banks, encourages investment projects to be financed more efficiently, thereby stimulating investment and output growth.

In explaining the causality evidence whether finance is an engine of growth or not Jayaratne and Strahan (1996) observed that rates of real per capital growth in income and output increased significantly following interstate bank reforms in USA. They also note that improvements in the quality of bank lending via branch banking and not increased volume of bank lending are responsible for growth changes. However, the causality direction seems to depend on the studied countries.

Jayaratne and Strahan (2002) investigated the methods to estimate the impact of changes in laws governing bank competition on entrepreneurial behaviour. They found that countries with more concentrated local banking markets have lower rates of incorporation, and when these countries opened their banking markets to external competition, the rate of incorporation increased. Thus, the removal of regulatory barriers increased bank competition, which in turn, caused higher rates of business incorporation.

Beck et al. (2000) also take advantage on the questions of unobserved heterogeneity and spurious casuality; though without considering industries as well as countries, but applying novel econometric techniques. They use a dynamic Generalized-Method-of Moment (GMM) panel estimator that allows simultaneously the exploitation of time series variation in the data to account for unobserved country-specific effects for the inclusion of lagged variables as regressors, and controls for endogeneity of all the explanatory variables. They also use an instrumental variable estimator in order to extract the exogenous component of financial intermediary development and found a positive effect of the financial development.
In Nigeria, several empirical attempts have been made to assess more generally the relationship between financial liberalization and economic performance (Soyibo and Adekanye, 1992; Ikhide and Alawode, 2001; Akpan, 2004). There exist other studies which examine the performance of financial sector reforms on economy across some sub - Sahara African countries (Soyibo, 1994; 1997; Emenuga, 1998; Aryeetey and Sebnet 1998; Aryeetey, 2000 among others).

For instance, Soyibo and Adekanye (1992) examine the links between interest rates, savings, investment and money supply in Nigeria. They found that there exists positive relationship between returns on financial assets and the rate of savings. They also showed that bank deposits are important in the level of productive investment in Nigeria. However, they cautiously noted that the general expectation in terms of the link between savings, investment and economic growth is ambiguous due to structural imperfections such as information asymmetries, moral hazards, and the likes.

Pradhan et al. (2013) examined the causal nexus between economic growth, banking sector development, stock market development, and other macroeconomic variables in ASEAN countries between 1961 and 2012 using panel vector auto-repression. The study showed that banking sector development Granger-causes economic growth. This result conforms with findings of Mezioghu and Walde-Rafael (2014) and Bojanic (2012) and Chaiechi (2012). Also, Dwyer et al. [2013] examined the relationship among banking crises, economic growth and recession covering 21 countries. They found evidence of mixed effects of either negative or positive on economic growth during the economic crisis but evidence of mixed results after the crisis.

\section{METHODOLOGY}

\section{Model specification}

Based on the arguments presented in the theoretical framework and the intuition from the reviewed literature, the model adopted in this study is the Schumpeterian Circular flow of creditary production (1934).The popular view underlying this theory is that a sectoral output of the entrepreneur will depend on banking reform measures, lending capacity of the banking system, and other conditioning variables that are capable of influencing the productivity of capital (A). Therefore, the relationship between banking sector reforms and output growth of the manufacturing sector via investible funds can be expressed as:

$M F G O_{t}=f\left(B F_{t}, L C_{t}, A_{t}\right) \ldots$

Where MFGO is the manufacturing sector output growth; BF is the measure of banking reforms that is proxied by real interest rates $(\mathrm{RR})$; interest rate spread (IRS); lending rates (LR); ratio of broad money $\left(\mathrm{M}_{2}\right)$ to nominal GDP as a measure Deposit Money Banks' liquid liabilities $\left(M_{2} / G D P\right)$. The lending capacity of the banking system is measured by ratio of Deposit Money Banks' assets to total banking assets (BA). $A$, in the model one represents those 
conditioning variables which could also determine the productivity of the invested capital. These variables include: power infrastructure (ENG); manufacturing capacity utilisation (MCU); trade openness as the degree to which the banking system is able to intermediate funds across borders, measured by ratio of imports plus exports to nominal GDP (TO) and exchange rate (EXR).

Therefore, in order to assess the effects of the banking reforms on the output growth of manufacturing sector in Nigeria, the following relationship was investigated:

$\mathrm{MFGO}_{\mathrm{t}}=f\left(\mathrm{LR}_{\mathrm{t}}, \mathrm{R} \mathrm{R}_{\mathrm{t}}, \mathrm{IRS}_{\mathrm{t}}, \mathrm{BA}_{\mathrm{t}}, \mathrm{TO}_{\mathrm{t}}, \mathrm{ENG}_{\mathrm{t}}, \mathrm{M}_{2} / \mathrm{GDP}_{\mathrm{t}}, \mathrm{EXR}_{\mathrm{t}}\right.$, $\mathrm{MCU}_{\mathrm{t}}$

This technique allows different measures of banking development to be expressed in terms of a single index (Stock and Watson, 2002 $a, b)$. Thus, the new proxy for the banking development, as denoted by BF, is able to capture most of the information from the original dataset which consists of the three financial development proxies. In order to test the links between the output growth of manufacturing sector and banking variables as well as those conditioning variables, we partially log-transformed equation (2) to have:

$\log \left(\mathrm{MFGO}_{\mathrm{t}}\right)=\beta_{0}+\beta_{1} \mathrm{LR}_{\mathrm{t}}+\beta_{2} \mathrm{RR}_{\mathrm{t}}+\beta_{3} \mathrm{IRS}_{\mathrm{t}}+\beta_{4} \log \mathrm{BA}_{\mathrm{t}}+\beta_{5} \log$ $\mathrm{TO}_{\mathrm{t}}+\beta_{6} \log \mathrm{ENG}_{\mathrm{t}}+\beta_{7} \log \mathrm{M}_{2} / \mathrm{GDP}_{\mathrm{t}}+\beta_{8} \mathrm{EXR}_{\mathrm{t}}+\beta_{9} \mathrm{MCU}_{\mathrm{t}}+\mu_{\mathrm{t}}$

Where: $\log$ MFGO is denoted as LnMFGO, measured by the index of manufacturing output; $\mathrm{BF}$ is proxied as a banking reforms variable; and is subdivided into: $L R$, LnBA, $\mathrm{LnM}_{2} / \mathrm{GDP}, \mathrm{EXR}$, IRS which is the spread between deposit and lending rates; and RR, which is the real deposit interest rate less the rate of inflation measured by GDP deflator, or lending rate less the interest rate spread; Log TO is the log sum of imports and exports measured as a share of GDP; Log ENG is the log of physical infrastructure proxied as industrial energy consumption index; EXR is the log of real effective exchange rate index; Log MCU is the log of manufacturing capacity utilization measured by the average capacity utilisation rates of the manufacturing sector.

The a priori expectations of the model in equation 3 is that we expect the banking variables $L R, R R$, IRS and EXR with an exception of $M_{2} / G D P$, to have inverse relationship with the output growth of manufacturing sector. But on the other hand, $M_{2} / G D P$ and all other conditioning variables such as BA, ENG, and MCU and TO in the model should have a positive relationship with the dependent variable, MFGO. $\beta_{0}$, is the constant and $\beta 1$ to $\beta_{9}$ are the coefficients, while $\varepsilon_{t}$ is the stochastic error term. Thus, $\beta_{1}, \beta_{2}, \beta_{3}$ and $\beta_{8}<0 ; \beta_{4}$, $\beta_{5}, \beta_{6}, \beta_{7}$, and $\beta_{9}>0$. However, the intercept values $\left(\beta_{0}\right)$ could either be positive or negative.

\section{Sources of data}

In order to investigate the relationship between banking reforms and output growth in manufacturing sector in the period 1970 to 2011 , the study made use of secondary data to obtain values for the variables in the model. Data were sourced from the publications of Central Bank of Nigeria Statistical Bulletin and Annual Report and Statement of Accounts (various issues). Data on manufacturing output were obtained from the publications of National Bureau of Statistics (NBS) and International Financial Statistics (IFS).

\section{Techniques of data analysis}

Engle and Granger (1987), demonstrated that co-integration variables must have an error correction representation in which an error correction term (ECM) must be incorporated into the model as in equation 4 :

$\begin{array}{lcccc}\Delta \text { Ln MFGO }_{\mathrm{t}}= & \lambda_{0} \mu_{\mathrm{t}-1}+{ }_{\lambda 1} \Delta \mathrm{Ln} \mathrm{BF}_{\mathrm{t}}+\lambda_{2} \Delta \mathrm{Ln} \mathrm{TO} \mathrm{TO}_{\mathrm{t}}+\lambda_{3} \Delta \mathrm{Ln} \mathrm{ENG}_{\mathrm{t}}+ \\ \lambda 4 \Delta \mathrm{EXR}_{\mathrm{t}} & + & \lambda_{5} & \Delta \mathrm{Ln} & \mathrm{MCU}_{\mathrm{t}}\end{array}$

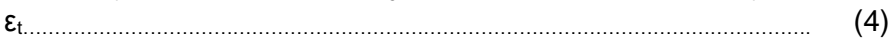

Here, $\Delta$ denotes first difference operator. $\mu_{\mathrm{t}-1}$ is the one period lagged value of the residual from the co-integration regression. The $\lambda_{0}$ coefficient of the error correction term captures the adjustment towards the long-run equation. $\varepsilon_{t}$ represents white noise with usual assumed zero mean and constant variance. Thus, Model 4 becomes the Error Correction Model.

\section{EMPIRICAL RESULTS}

It is pertinent to examine the statistical properties of the data series. All the time series data employed in the analysis were subjected to stationarity test. The two conventional tests employed are Augmented Dickey Fuller (ADF) and Philips-Perron (PP) tests. The results of the two tests are reported in Table 1.

As shown in the table, we use both the argumented Dickey-Fuller (ADF) and the Phillips-Perron Statistics. It was found that all the variables except the interest rate (RR) exhibit non-stationarity at their levels but stationary at their first differences.

The ADF and Phillips -Perron tests are carried out against the null hypothesis that there is unit root, that is, I (1), non-stationary of the series. With a sample size of 39 , the critical values for the ADF and Phillips-Perron (without trend) at $1 \%$ and $5 \%$ significance levels are -3.62 and -2.94 respectively. Absolute values of ADF and Phillips-Perron values are less than critical values indicate a rejection of the null hypothesis. The results of the test as reported above indicates that both the ADF and Phillips-Perron test Statistics confirmed that differencing the variables once will guarantee their stationarity. Since the series were integrated of order one or I (1) in the terminology of Engel and Granger (1987), and their first differences were stationary, consequently the presence of significant cointegrating relationships among the variables were thereby determined.

\section{Test of Cointegration}

Cointegration analysis helps to clarify the long-term relationships between the integrated variables. A major defect of the unit root test is that it cannot discriminate between true and near true random walks processes. Thus, it became necessary to perform additional tests to show that the variables of the model are cointegrated. The establishment of long-term convergence, i.e, long-run equilibrium between the variables enables us to carry out estimations using cointegration and error correction model 
Table 1. Unit Root test- of the series -without trend (1970-2008).

\begin{tabular}{lccccc}
\hline \multicolumn{2}{c}{ At Levels } & \multicolumn{2}{c}{ At First Differences } & \\
\hline Variable & ADF & Philips-Peron & ADF & Philips Peron & Order of Integration \\
\hline LMFGO & -0.957334 & -0.798496 & -3.68888 & -6.363431 & $\mathrm{I}(1)$ \\
LR & -1.414182 & -1.818578 & -6.573497 & -9.413967 & $\mathrm{I}(1)$ \\
LBA & -2.174196 & -2.250320 & -4.86379 & -5.696275 & $\mathrm{I}(1)$ \\
LENG & 0.048759 & 0.152184 & -4.34274 & -6.073509 & $\mathrm{I}(1)$ \\
IRS & -1.238686 & -1.791809 & -6.53241 & -9.649741 & $\mathrm{I}(1)$ \\
MCU & -1.637037 & -1.450511 & -5.27572 & -3.703099 & $\mathrm{I}(1)$ \\
LM $/$ GDP & -2.178290 & -1.980600 & -4.01854 & -5.722682 & $\mathrm{I}(1)$ \\
RR & -4.071365 & -3.627312 & - & - & $\mathrm{I}(0)$ \\
EXR & -1.342729 & -1.367673 & -3.67031 & -5.330762 & $\mathrm{I}(1)$ \\
LTO & -1.733006 & -2.455093 & -5.04045 & -9.388213 & $\mathrm{I}(1)$ \\
\hline
\end{tabular}

Source: Compiled by the author.

Table 2. Johansen cointegration test assumption of linear deterministic trend in the data series: EXR, LBA, LENG, IRS. LR, LM2/GDP, MCU, LMFGO, LTO, RR.

\begin{tabular}{lcccc}
\hline Eigen value & Likelihood ratio & $\mathbf{5 \%}$ critical value & $\mathbf{1 \%}$ critical value & Hypothesized No. of CE (s) \\
\hline 0.986403 & 479.9538 & 233.13 & 247.18 & Non ${ }^{* *}$ \\
0.934444 & 329.5270 & 192.89 & 204.95 & At most $1^{\star *}$ \\
0.794641 & 234.1573 & 156.00 & 168.36 & At most $2^{\star *}$ \\
0.727961 & 178.7525 & 124.24 & 133.57 & At most $3^{\star *}$ \\
0.651693 & 133.18991 & 94.15 & 103.18 & At most $4^{\star *}$ \\
0.635612 & 96.27568 & 68.52 & 76.07 & At most $5^{\star *}$ \\
0.529476 & 60.94195 & 47.21 & 54.46 & At most $6^{\star *}$ \\
0.418618 & 34.55514 & 29.68 & 35.65 & At most $7^{*}$ \\
0.333348 & 15.57299 & 15.41 & 20.04 & At most 8 \\
0.038687 & 1.380936 & 3.76 & 6.65 & At most 9 \\
\hline
\end{tabular}

$\left.{ }^{*}{ }^{* *}\right)$ denotes rejection of the hypothesis at $5 \%(1 \%)$ significance level. Likelihood ratio test indicates 9 co-integrating equation(s) at 5 per cent significance level.

(ECM), estimate our models. The Johansen Maximum Likelihood procedure was therefore employed and the results are presented in Table 2. As stated in Table 2, the result shows that 9 co- integrating equations are found to exist among the variables. By implication, there is a long run relationship among the variables because there is at least the presence of one cointegrating vector, which suffices to confirm cointegrating relations. Specifically, the results of the cointegration test suggest that banking reform and conditioning variables at first differences converge in the long run.

It was important to note that the existence of cointegration vectors among a group of variables might not imply that there was causal influence or relationship between pairs of variables included in the model involving cointegrated variables. Consequently, the existence of equilibrium between a group of variables should not be interpreted to mean that equilibrium exist between all pairs of variables in the model. Thus, the changes in the banking reform variables might not have had significant impact on manufacturing sector's output growth which perhaps might have been induced by other variables included in the models which might be responsible for the possible long run relationship.

The result from the normalized equation with respect to MFGO is:

LMFGO $=7.849 *$ LR $+0.2056{ }^{*} \mathrm{RR}-0.738 *$ IRS + 1.0350 * LBA + 10.4408 * LTO -0.2643 * LENG $8.4888^{*} \mathrm{LM} 2 / \mathrm{GDP}+0.03452{ }^{*} \mathrm{EXR}-0.1015^{*} \mathrm{MCU}$

None of the banking variables has the apriori signs except interest rate spread (IRS). A decrease of 1 per cent in the interest rate spread (IRS) leads to an increase 
in manufacturing output (MFGO) by about 0.7 per cent. But on the other hand, a decrease of 1 per cent in the real rate of interest will result in 0.2 per cent decrease in manufacturing output growth. Similarly, a reduction in lending interest rate (LR) by 1 per cent will also lead to a decrease in manufacturing output (MFGO) by about 8 per cent. Moreover, a 1 per cent increase in the financial is deepening indicator (M2/GDP) leads to a decrease in MFGO by about 8 per cent. The effects of exchange rate (EXR) on MFGO also do not conform to the apriori negative signs. This is an indication of weak effects of banking sector reforms experience in Nigeria.

The lending capacity of the banking system measured by the ratio of DMBs' assets to aggregate banking assets (BA) does not have the expected positive sign. It has coefficient value of -1.03 . This implies that an increase of 1 per cent in banks' assets leads to 1 per cent increase in MFGO. This is not to say that lending capacity of banks is not important in determining the quantity of bank credits to the manufacturing sector, but it probably reflects a case of credit diversion from the real sector to consumer credit markets.

In the same vein, the signs of the coefficients of most of the conditioning variables on manufacturing sector output are negative and thus do not conform to the apriori expectations. A 1 per cent increase in the ratio of net exports to GDP (TO) results in about 10 per cent increase in MFGO. The effects of power infrastructure on output of manufacturing sector which shows a negative sign does not conform to the expected positive sign. This confirms the evidence that in Nigeria, over the years, power infrastructure plays insignificant role in bringing about increased output. Thus, an increase of 10 per cent in manufacturing capacity utilization will brings about an increase of only 0.1 per cent in output growth of manufacturing sector.

The focus in this section is to present the over parameterised version of the error correction model as well as the parsimonious version. The contemporaneous as well as the lag variables presented are in their loglinear form which implies that the coefficient estimates in all the models are elasticities showing the percentage changes in the exogenous variables that condition the percentage change in the endogenous variable (manufacturing output growth).

The over parameterised banking sector reform model is simplified until theory-consistent and data-coherent results are achieved by one by one deleting of the insignificant variables. Both Schwarz and Akaike information criteria show that the parsimonious model is a better model than the over parameterised model because of the reduction in their values from -1.738979 and -3.190138 to 0.737941 and -0.305079 . This is an indicative of the robustness of the parsimonious model.

To ensure the validity of the estimates of the parsimonious model in table 3 , tests to verify the extent of the violations of the assumptions of Ordinary Least Squares estimates were carried out.

The first test is the Breusch-Godfrey Serial Correlation LM test presented in Table 4.

The probably of F-statistic at 5 per cent significance level shows that the null hypothesis of no serial correlation cannot be rejected.

The second test carried out is the Autoregressive Conditional Heteroskedasticity (ARCH) test to verify the presence of Heteroskedasticity in the error term. This is presented in Table 5.

The ARCH result in Table 5 shows that the null hypothesis of the absence of $\mathrm{ARCH}$ effects cannot be rejected at 5 per cent significance level. On the basis of the two tests presented in tables 4 and 5 , the parsimonious model results could largely be relied upon.

A critical look at the parsimonious model results presented in table 3 shows that the past values of manufacturing output were positively related to its current value, and equally significant. As a result a 1 per cent increase in a year lagged period value of manufacturing output will bring about 44 per cent increase in the current value of manufacturing output. Similarly, 1 per cent increase in the two year lagged periods will equally result in 69 per cent increase in the current value of manufacturing output.

While the a priori expectation of the signs was met in a year lagged period values of lending rate and interest rate spread, other variables like exchange rate, current bank assets, two-year lagged value of interest rate spread, two-year lagged value of power infrastructure, financial depth indicator at level, past and current values of interest rates were not properly signed even though significant. In fact, the positive signs on lending rate and real interest rate contradict the theoretical prediction according to which a higher cost of capital would discourage productive activity by entrepreneurs. However, the current value of power infrastructure, a year lagged period value of interest rate spread and two-year lagged period value of financial depth indicator met the apriori expectations of the sign.

The Dummy variable introduced into our regression model in order to capture the effect of the regime shift from financial regulation to deregulation of the banking sector in 1986 was found to be positive but not significant. However, the Dummy variable was still left in the parsimnious model even though its effect on the robustness of our analysis was marginal.

The overall regression is significant. All the variables, besides current interest rate are significant at 5 per cent significance level. The results also show that the error correction term (ECM) is negative and at the same time significant with a very low probability value of 0.0229 . In other words, the negative coefficient of ECM signifies that there is an adjustment in the system in case of any disequilibrium. Thus, about 23 percent of the 
Table 3.The parsimonious error correction model of DLMFGO.

\begin{tabular}{lcccc}
\hline Variable & Coefficient & Std.Error & t-statistics & Prob. \\
\hline DLMFGO(-1) & 1.263013 & 0.327758 & 3.853496 & 0.0032 \\
DLBA & 0.768793 & 0.316803 & 2.426723 & 0.0356 \\
DLTO & 0.733921 & 0.277698 & 2.642880 & 0.0246 \\
DLTO(-1) & 1.095502 & 0.452477 & 2.421124 & 0.0360 \\
DLTO(-2) & 1.633461 & 0.444211 & 3.677217 & 0.0043 \\
DIRS(-1) & -0.223427 & 0.069048 & -3.235835 & 0.0089 \\
DIRS(-2) & 0.116227 & 0.060301 & 1.627436 & 0.0828 \\
DLENG & 0.294257 & 0.088106 & 3.339816 & 0.0075 \\
DLENG(-2) & -0.171697 & 0.110078 & -1.559775 & 0.1499 \\
DLM2/GDP & -3.366537 & 0.694231 & -4.849304 & 0.0007 \\
DLM2/GDP(-2) & -1.456169 & 0.374284 & -3.890546 & 0.0030 \\
DLR(-1) & 0.184419 & 0.051895 & 3.553726 & 0.0052 \\
DLR(-2) & -0.105693 & 0.051011 & -2.071962 & 0.0651 \\
DLR & 0.166217 & 0.056040 & 2.966060 & 0.0141 \\
DRR(-2) & 0.022400 & 0.006413 & 3.492748 & 0.0058 \\
DIRS & -0.259540 & 0.078882 & -3.290240 & 0.0080 \\
DEXR(-1) & 0.028514 & 0.006099 & 4.674815 & 0.0009 \\
DEXR(-2) & 0.011534 & 0.003461 & 3.332300 & 0.0076 \\
DUM & 0.179034 & 0.127227 & 1.407208 & 0.1897 \\
ECM(-1) & -0.2394704 & 0.891977 & -0.2684714 & 0.0229 \\
\hline
\end{tabular}

$R^{2}=0.84 ; S . E=0.19 ; \quad F=2.3503 \quad D W=1.915 ; R S S I=0.3533 ; \quad S . C=0.7379 ; \quad A K \quad I N F O=-0.3050$. Source: Compiled by the authors

Table 4. Breusch-Godfrey Serial Correlation LM Test.

\begin{tabular}{llll}
\hline F-statistic & $\mathbf{1 . 3 2 0 9 7 4}$ & Probability & $\mathbf{0 . 2 8 3 5 7 6}$ \\
\hline Obs $^{*}$ R-squared & 3.385340 & Probability & 0.184027 \\
\hline
\end{tabular}

Table 5. Autoregressive conditional Heteroskedasticity (ARCH) result.

\begin{tabular}{llll}
\hline F-statistic & $\mathbf{1 . 4 1 5 5 0 1}$ & Probability & $\mathbf{0 . 2 5 3 7 1 0}$ \\
\hline Obs $^{*}$ R-squared & 5.553867 & Probability & 0.235035 \\
\hline
\end{tabular}

disequilibrium in the output growth of manufacturing sector in the previous year is automatically corrected in the current year. This also appears significant demonstrating the fact that domestic and endogenous factors go a long way in explaining output growth of manufacturing sector in Nigeria.

The implication of the above analysis is that the contemporaneous values of the banking variables used in the study appear not to impact positively on the output growth of manufacturing sector during the period under review. Thus, it becomes evident that the banking industry is inefficient and uncompetitive given the negligible impact the sector had on the manufacturing activity. However, the results show that the past (lags $1 \&$ 2) values of both banking variables and manufacturing output, as well as the values of other conditioning variables were responsible for the growth of manufacturing output in Nigeria during the period. The finding contradicts the position of Ikhide and Alowode (2001) which supported the positive role of financial development in banking sector growth in Nigeria.

\section{CONCLUSION AND POLICY IMPLICATIONS}

Overall, the study found that the expectations of 
increased output growth of the manufacturing sector in Nigeria in the wake of banking reforms are still far from being realized. The coefficients of banking development indicators show a negative impact of banking reforms on output growth of manufacturing sector. The results of the Nigeria-specific study confirmed that the Nigerian banking industry has not been efficient in ameliorating informational asymmetries, reducing transaction costs and allocating resources to the manufacturing sector. This indicates that the Nigerian banking sector has not considerably played its legitimate role of channeling financial credits to the manufacturing sector regarded as an engine of growth.

It is therefore pertinent to suggest that the extant banking sector reforms in Nigeria need to be carefully reviewed and closely monitored. This calls for sound institutional and legal framework and sound corporate governance aimed at reducing structural lapses and corruption level. This steps will create an enabling environment for banking sector to operate and ensure that the sector positively impact on the manufacturing sector output growth.

In addition, the policymakers must be prepared to initiate proper alternative banking reforms that will serve as counter measures to lessen or abort the negative impacts on the manufacturing output growth caused by any banking reforms. Thus a flexible accommodating banking reform regime is advocated for Nigeria.

\section{Conflict of Interests}

The authors have not declared any conflict of interest.

\section{REFERENCES}

Akingbola BO (2001). "Strategies for Effective Management of Financial Institutions in the New Millennium" $J$ the Chartered institute of Bankers of Nigerian (CIBN), Lagos.

Akpan DB (2004). "Financial Liberalization and Endogenous Growth: The case of Nigeria". AIDEP Publication 32(2):1-4.

Aryeetey E, Sebnet L (1998). "Essential Financial Market Reforms in African" Background Paper for "Can Africa Claim the $21^{\text {st }}$ Century"? World Bank.

Aryeetey E (2000). "Recent Development in African Financial Market: Agenda for Further Research". Paper presented at the plenary Session of the Biannual Research Workshop of the AERC, Nairobi, Kenya December 2-7, pp.111-152.

Beck T, Levine R, Loayza N (2000). "Finance and the sources of Growth" J Financ. Econ. 58:261-300

Bencivenga VR, Smith BD (1991). "Financial Intermediation and Endogenous Growth". Review of Econ. Stud. 58:195-209

Bojanic A.M. (2012). The Impact of Financial development and Trade on the Economic Growth for Bolivia. J. Apppl. Econ. 115(j):51-70.

Bukhari MS (2005). "Banking and Economic Growth: Case of the Gambia" Inaugural-Dissertation Christian-Albrechts-Universtitaet, zu Kiel 2005.

Carbo S (2007). "Financial Innovations in Banking; Impact on Regional Growth" Department of Economic, University of Granada, Spain.

CBN (2008). Statistical Bulletin, Central Bank of Nigeria, Abuja.
Chaiechi T (2012). Financial Development shocks and Contemporaries feedback effort on key macroeconomic indicators: A post Keynesian Time Series analysis, Econ. Model. 29(2):487-501.

Dickey D, Fuller WA (1981). "Likelihood ratio statistics for Autoregressive Time Series with a Unit Root," Econometrical, 49: 1057-1072.

Dwyer GP, Devereux J, Baler S, Tamura R (2013). Recession, Growth and Banking Crises. J Int. Money Financ. 38:18-40.

Engle RF, Hendry DF, Richard J (1987). " Exogeneity”. Econometrica 51: 277-304.

Emenuga C (1998). "The outcome of the Financial Sector Reforms in West Africa" In Ediz (ECLS) Economic Reforms, Sub-Sahara, Africa IDRC Ottavia.

Fama EF (1980). "Banking in the Theory of Finance" J. Monet. Econ. 6:39-57.

Graff MA, Karmann A (2001). "Does Financial Activity Cause Economic No. 1/01, Techno Growth?" Dresden Discussion paper Series in Economics No. 1/01, Technische Universitat Dresden.

Greenwood J, Jovanovic B (1990). "Financial Development, Growth and the distribution of Income, J Polit. Econ. 98: 1076-1108.

Hamilton A (1781). http:/www.worldbank.org/research/conference/ finance. U.S.treasury/financeDept./Version23.pdf.

Ikhide SI, Alawode AA (2001). "Financial Score Reforms, Macro Economic Instability and the order of Economic Liberalization: The Evidence form Nigeria" AERC Research Paper 112, November.

Jayaratne J, Strathan PE (1996). "Financial - Growth Nexus: Evidence from Bank Branch Deregulation”, Quart. J Econo. III, Pp. 693-670.

Jayaratne J, Strathan PE (2002). "Financial - Growth Nexus: Evidence from Bank Branch Deregulation”, Q. J. Econ. 3:693-670.

Johansen S, Juselius K (1992). "Some structural Hypothesis in a multivariate Co-integration Analysis of Purchasing Power Parity and Uncovered Interest Parity for the U.K." J. Econ. 53:211-244.

King RG, Levine R (1993a). "Financial and Growth: Schumpeter Might be Right" Quart. J Econ. 108(3):717-737.

King RG, Levine R (1993b). "Finance, Entrepreneurship, and Growth: Theory and Evidence", J Monetary Econ., 32: 513-542

Levine R, Loayza N, Beck T (2002). "Financial Intermediation and Growth; Causality and Causes" J. Econ. Lit., 46:31-77.

Levine R (1997). "Financial Development and Economic Growth: View and Agenda. J. Econ. Lit. 35:688-726.

Loayza NK, Schmidt-Hebbel LS (2000). "What Drives private Savings across the World"? Rev. Econ. Stat. 82(2).

Mezioghu K, Walde-Rufael Y (2014). Financial development, trade operations and economic growth in African countries: New Insight for Panel Casualty Appraisal, Econ. Productivity 37(2):386-394.

Pradhan RP, Amir MB, Hall JH, Bahmoni (2014). "Causal Nexus Between Economic Growth, Banking Sector Development, Stock Market Development And Other Macroeconomic Variables The Case Of AESAN Countries. Rev. Financ. Econ. 23:155-173.

Robinson J (1952). "The Generalization of the General Theory, in" The Rate of Interest and other Essays, Macmillan, London, pp.67-142

Schumpeter JA (1934). "The Theory of Economic Development, Oxford University Press.

Soyibo A, Adekanye F (1992). "Financial System Regulation, regulation and Savings Mobilization in Nigeria "AERC Research paper 2.

Soyibo A (1994). "Financial Liberalization and Bank Restructuring in Sub-Saharan Africa: Some Lessons for Sequencing and Policy Design" Plenary Paper, AERC December, pp.4-9.

Soyibo A (1997). "Banking Sector Reforms in Africa, Effects on Savings, Investment and Financial Development" Afr. Dev. Rev. 9(1).

Stock JH, Watson MW (2002a). "Macroeconomic Forecasting Using Diffusion Indexes. J. Bus. Econ. Stat. 20:147-163.

Stock JH, Watson MW (2002b). "Forecasting Using Principal Components from Large Number of Predictors. J. Am. Stat. Assoc. 97:1167- 1179 .

Winkler A (1998). "Financial Development, Economic Growth and Coorporate Governance" Johann Wolfgang Goethe Universitaet, Frankfurt, AM Main, Working paper Series: Finance No 12. 


\section{Appendix A:}

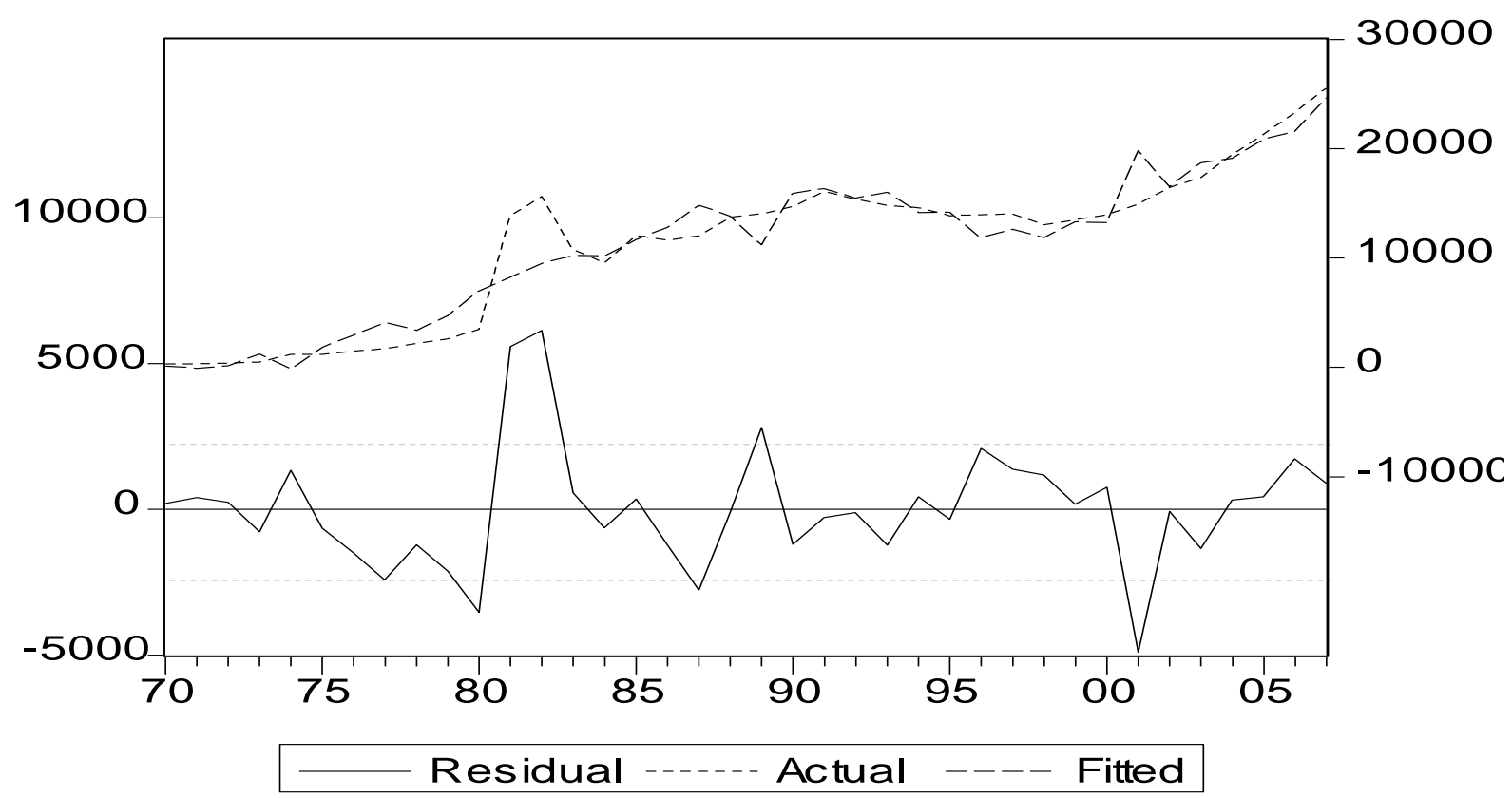

Figure 1. Actual and Fitted graphs of MFGO model

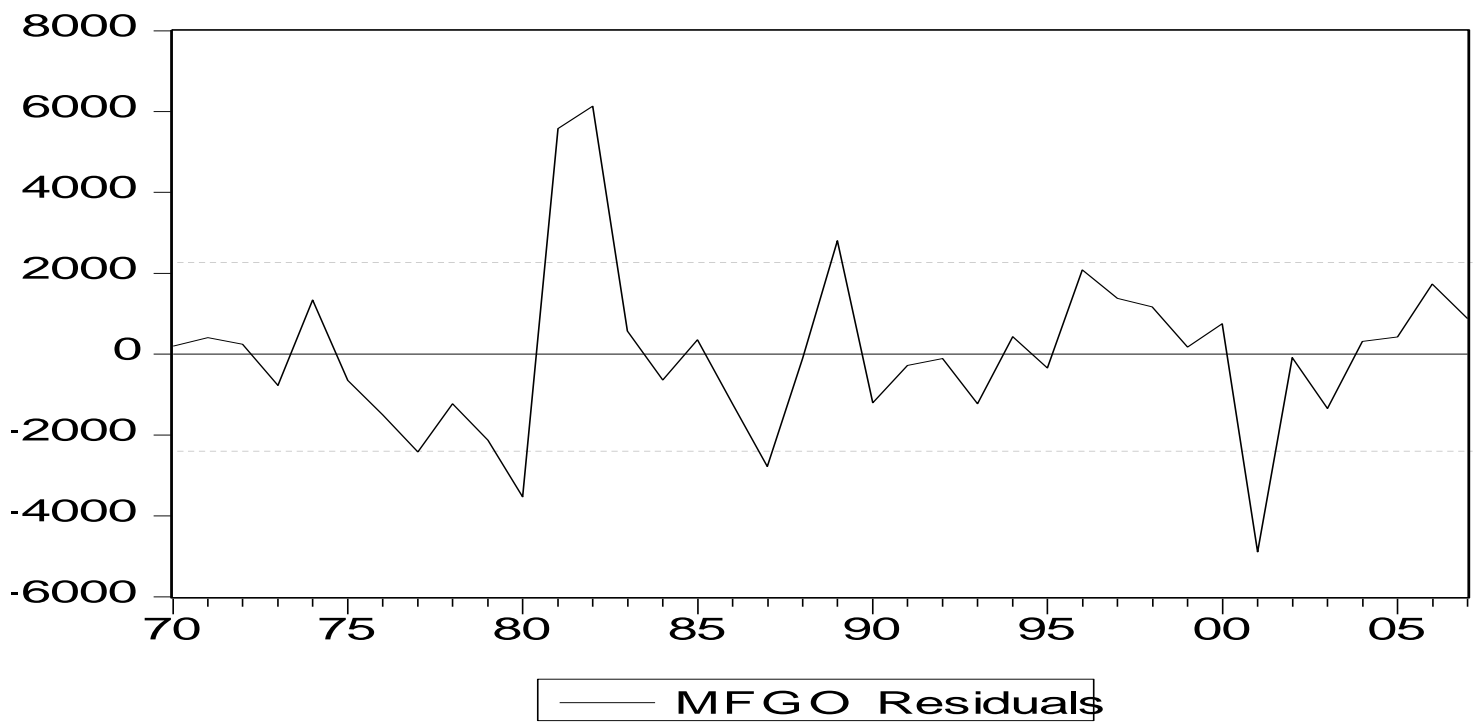

Figure 2. The residual graph of the MFGO model. 